\title{
KINERJA PENDAMPINGAN USAHA RINTISAN BINAAN PADA ORANGENEST INCUBIZ
}

\author{
Septiana Ayu Estri Mahani \\ Fakultas Ekonomi dan Bisnis-Manajemen, Universitas Islam Bandung (Unisba) \\ estrimahani@gmail.com
}

\begin{abstract}
ABSTRAK
Penelitian ini bertujuan untuk mengevaluasi kinerja Inkubator Bisnis dan Teknologi dalam pendampingan usaha rintisan binaan. Kinerja Inkubator Bisnis Teknologi Orangenest dalam aspek manajemen masih kurang optimal. Jika dilihat dari proyek yang harus dikerjakan, tenaga pengelola dan pendamping masih kurang kompeten. Dukungan dari Pemerintah berupa sosialisasi Peraturan Presiden RI Nomor 27 Tahun 2013 mengenai peranan inkubator bisnis dalam pendampingan usaha tenant juga masih belum optimal. Penelitian dilakukan di Inkubator Bisnis Orangenest Incubiz di Kota Bandung dan dengan mewawancarai pengelola dan tenant inkubator. Jenis penelitian ini adalah deskriptif kuantitatif. Data yang digunakan dalam penelitian ini adalah data primer dan sekunder. Data yang diperoleh dianalisis dengan metode balanced scorecard (BSC). Hasil penelitian ini menunjukkan, skor pencapaian kinerja Inkubator Bisnis Teknologi Orangenest Incubiz sebesar 41,328 .
\end{abstract}

Kata Kunci: Balanced Scorecard (BSC), Inkubator Bisnis dan Teknologi, Kinerja Inkubator

\section{ABSTRACT}

This study aims to evaluate the performance of Business and Technology Incubators in mentoring pilot businesses. The performance of the Orangenest Technology Business Incubator in management aspects is still not optimal. If seen from the project that needs to be done, the management and escort staff are still less competent. Government support in the form of socialization of the Republic of Indonesia Presidential Regulation Number 27 of 2013 concerning the role of business incubators in assisting tenant businesses is still not optimal. The research was conducted at the Orangenest Incubiz Business Incubator in Bandung City and by interviewing incubator managers and tenants. This type of research is quantitative descriptive. The data used in this study are primary and secondary data. The data obtained were analyzed by the balanced scorecard (BSC) method. The results of this study indicate, the performance achievement score of Orangenest Incubiz Technology Business Incubator was 41,328 .

Keywords: Balanced Scorecard (BSC), Business and Technology Incubator, Incubator Performance

\section{PENDAHULUAN}

\section{Latar Belakang}

Pertumbuhan penduduk Indonesia dari tahun ke tahun terus mengalami peningkatan. Badan Perencanaan Pembangunan Nasional (Bappenas) memproyeksikan bahwa pada tahun 2035 jumlah penduduk Indonesia mencapai 305,6 juta jiwa atau naik sebesar 28,6 persen dari tahun 2010. Meningkatnya jumlah penduduk Indonesia menjadikan Indonesia sebagai negara kelima dengan jumlah penduduk terbanyak di dunia. Fenomena peningkatan jumlah penduduk Indonesia tersebut bersamaan dengan meningkatnya jumlah penduduk usia produktif (usia 15 tahun sampai 65 tahun) (http://nasional.kompas.com). Menurut BPS 
(2013), Indonesia telah memasuki bonus demografi (rasio ketergantungan) sejak tahun 2012, yakni 49,6 persen. Rasio ketergantungan (dependency ratio) adalah perbandingan antara jumlah penduduk umur 0-14 tahun, ditambah dengan jumlah penduduk 65 tahun ke atas (keduanya disebut dengan bukan angkatan kerja) dibandingkan dengan jumlah penduduk usia 15- 64 tahun (angkatan kerja).

Wirausaha atau yang lebih dikenal dengan entrepreneur menjadi sangat populer di tanah air dalam satu dekade terakhir. Hal ini disebabkan oleh ketahanan wirausaha sebagai pengelola Usaha Kecil dan Menengah dalam menghadapi krisis nasional yang terjadi. Ketika krisis nasional terjadi, UKM tetap berdiri kokoh disaat perusahaan-perusahaan besar bertumbangan. Wirausaha dianggap sebagai salah satu penggerak perekonomian nasional karena kemampuannya dalam menciptakan lapangan pekerjaan, kemampuan dalam menyajikan berbagai macam inovasi, serta diversitas (keberagaman) yang menawarkan kesempatan bagi para invidu untuk mengekspresikan dirinya.

Upaya dalam mewujudkan percepatan pertumbuhan ekonomi di berbagai daerah melalui pembentukan wirausaha baru disambut dengan baik oleh berbagai pihak. Beberapa tahun terakhir, dukungan dari berbagai pihak untuk mewujudkan hal tersebut sangat besar, baik dari pemerintah, dunia usaha maupun perbankan. Pemerintah mewujudkan hal tersebut melalui pendirian Kementrian Koperasi dan Usaha Kecil dan Menengah. Kalangan dunia usaha pun memberikan dukungan melalui program-program berbentuk pembinaan usaha kecil dan menengah berupa bantuan pinjaman modal serta pelatihan-pelatihan hingga bantuan pemasaran. Dunia perbankan mendukung program pembentukan wirausaha baru melalui penyaluran kredit lunak kepada usaha kecil dan menengah bahkan ada salah satu bank pemerintah yang mengadakan kompetisi wirausaha.

Secara umum, inkubator adalah organisasi yang menyediakan infrastruktur dan pelayanan yang menaikkan nilai tambah suatu usaha. Inkubator bisnis memberikan ide dan konsep dari "technopreneurs" pada tahap pertama (awal) menjadi rencana dan implementasi usaha. Secara operasional dalam rangka mengembangkan wirausaha baru yang tangguh dan unggul, inkubator bisnis memberikan bantuan pembinaan serta pelatihan yang didukung oleh fasilitas/akses teknologi, manajemen, pasar, modal, serta informasi secara umum maupun spesifik (BI, 2006). Pengembangan inkubator bisnis di Indonesia telah dirintis sejak tahun 1993 namun perkembangannya belum memuaskan (Idris, 2012).

Inkubator Bisnis dan Teknologi Orangenest Incubiz merupakan salah satu Inkubator Bisnis dan Teknologi Independen, yang memperoleh dana secara swadana melalui kegiatan pelatihan dan berkolaborasi dengan beberapa kampus di Kota Bandung dan Jakarta, Pada tahun 2018 Orangenest Incubiz mengikuti Pendampingan Inkubator Bisnis dan Teknologi INBISTEK dari Kementerian Industri untuk menjadi suatu inkubator multiguna. Tujuan dari INBISTEK adalah mengembangkan jiwa kewirausahaan berbasis teknologi (technopreneur) para lulusan perguruan tinggi, generasi muda, dan pebisnis baru lainnya yang berkembang dari usaha baru dan menggunakan kreasi pengembangan riset dan prototype dari lembagalembaga pelatihan dan universitas di wilayah Kota Bandung. Program inkubasi bisnis Orangenest Incubiz terdiri dari tiga tahap program inkubasi yaitu seed incubator, start-up, dan after care programme (www.orangenest-incubator.com).

Mengingat peranan inkubator bisnis yang cukup krusial dalam meningkatkan jumlah wirausaha baru, maka kinerja inkubator bisnis harus dievaluasi secara berkala. Inkubator 
bisnis dengan banyak mitra tentu perlu di manage dengan baik oleh tenaga kerja yang handal dan berkualitas. Selain itu, pemerintah sebagai regulator yang memberi otoritas dalam pengaturan iklim usaha di suatu negara juga perlu mensosialisasikan pentingnya keberadaan inkubator bisnis agar pemilik dan pengelola inkubator bisnis dapat memberikan manfaat bagi lebih banyak lagi tenant UKM. Berdasarkan masalah yang dikemukakan, maka penulis tertarik untuk meneliti aspek manajemen di Orangenest Incubator dan dampak keberadaannya bagi Start Up di Indonesia.

\section{Rumusan Masalah}

Berdasarkan latar belakang di atas, beberapa identifikasi masalah adalah (1) Bagaimana aspek manajemen Orangenest Incubator? (2) Bagaimana kinerja pelaksanaan inkubator bisnis di Orangenest Incubator dalam pendampingan usaha rintisan (Start-Up)? (3) Bagaimana manfaat program inkubasi terhadap kinerja usaha rintisan $($ Start-Up)?

\section{LANDASAN TEORI}

\section{Model Inkubator}

Inkubator bisnis telah lama dikembangkan di beberapa negara maju, upaya pendirian inkubator sendiri telah dimulai sejak tahun 1959. Tenant pertama yang dibina dalam inkubator adalah usaha pengecatan papan petunjuk di New York dengan luas ruangan 1.919,6 meter persegi. Gerakan pendirian inkubator dilakukan di Amerika Serikat, Kanada, Eropa dan Australia. Di Amerika Serikat, inkubator telah berkembang sejak awal tahun 1980-an. Perkembangan inkubator lebih lanjut terjadi di negara berkembang pada pertengahan tahun 1990-an, hingga mencapai angka 4.000. Jumlah inkubator pada tahun 2000 sebanyak 3.450. Perbedaan jumlah tersebut karena adanya penggolongan antara inkubator yang didirikan pemerintah dengan inkubator yang didirikan oleh swasta yang berorientasi laba. Diperkirakan jumlah inkubator di dunia lebih dari 3.500 inkubator dan sebagian besar diantaranya terletak di Amerika Serikat dan negara-negara Eropa.

Malano (2011) menjelaskan inkubator bisnis pertama kali diperkenalkan di New York dimana sebuah gedung yang sebelumnya digunakan untuk melakukan inkubasi terhadap ayam kemudian dirubah penggunaannya untuk menginkubasi perusahaan pemula (start up firm). Konsep inkubator bisnis kemudian diadopsi oleh sejumlah negara dan meluas ke berbagai negara sebagai sebuah media untuk melakukan pendekatan bisnis yang berkelanjutan dengan harapan menjadi potensial bisnis yang tinggi.

Peraturan Presiden RI Nomor 27 Tahun 2013 tentang Pengembangan Inkubator Wirausaha, mendefinisikan inkubator sebagai berikut: "inkubator sebagai suatu lembaga intermediasi yang melakukan proses inkubasi terhadap peserta inkubasi (tenant, klien inkubator, atau inkubasi) dan memiliki bangunan fisik untuk ruang usaha sehari-hari bagi peserta inkubasi. Inkubasi adalah suatu proses pembinaan, pendampingan, dan pengembangan yang diberikan oleh inkubator wirausaha kepada peserta inkubasi. Kegiatan usaha tenant dapat dilakukan di dalam gedung inkubator sebagai tenant inwall dengan menyewa ruangan yang disediakan inkubator.

Dipta (2003) mengungkapkan beberapa alasan yang mendasari pendirian inkubator menjadi sangat penting karena pada umumnya usaha kecil sangat rentan terhadap kebangkrutan terutama pada fase start-up. Sejumlah ahli menyatakan bahwa pada fase start- 
up, usaha kecil diibaratkan sebagai bayi yang masih prematur yakni bayi yang belum siap untuk dilahirkan sehingga kondisinya masih sangat rentan. Pada masa seperti ini, diperlukan penanganan khusus, misalnya melalui inkubasi sehingga sang bayi dapat hidup sebagaimana bayi yang dilahirkan normal dan dapat terhindar dari resiko kematian. Sistem inkubasi inilah yang terbukti dapat diadopsi sebagai suatu bagian dari strategi pembinaan usaha kecil di sejumlah 15 negara.

Berdasarkan kepemilikan, Coopers (1999) mengklasifikasikan inkubator menjadi empat kategori: 1) Standalone, inkubator yang dimiliki dan dijalankan oleh pihak independen yang tidak berfungsi sebagai unit bisnis dan terpisah dari induk yang menaunginya. 2) Embedded, inkubator yang tidak terpisahkan dari induk yang menaunginya, misalnya dimiliki dan dijalankan oleh lembaga pembangunan daerah. 3) Networked, inkubator yang dijalankan berdasarkan kerjasama formal dengan inkubator lainnya, baik dalam bentuk kepemilikan atau manajemen maupun melalui penyediaan jasa atau informasi bersama. 4) Virtual, inkubator yang menyediakan jasa yang sebagian besar melalui jaringan komunikasi dari jarak jauh.

Setidaknya terdapat lima bentuk generik inkubator bisnis yang telah berkembang selama 40 tahun (Campbell et al, 1987) : 1) Industrial incubators, inkubator yang disponsori oleh pemerintah dan lembaga non-profit dengan tujuan menciptakan lapangan pekerjaan, dan biasanya sebagai respon terhadap pemutusan hubungan kerja (PHK) atau pengangguran. 2) University-related incubators, inkubator yang dibentuk dengan tujuan untuk mengkomersialisasikan ilmu, teknologi dan hal intelektual yang dihasilkan perguruan tinggi. 3) For-profit property development, inkubator yang menyediakan ruang kantor dan workshop/tempat produksi untuk disewakan serta layanan lainnya. 4) For-profit investment incubators, inkubator yang didirikan dengan tujuan bagi perusahaan modal ventura untuk memiliki perusahaan dalam portofolio mereka. Hal ini dapat memungkinkan perusahaan modal ventura untuk menciptakan sinergi dalam portofolionya. 5) Coporate venture incubators, merupakan salah satu model inkubator yang pertumbuhannya paling cepat dan paling sukses.

Setiap pendiri dan tim manajemen inkubator harus melaksanakan hal-hal sebagai berikut untuk mencapai keberhasilan: 1) Menjalankan dua prinsip pengelolaan inkubator bisnis; 2) Mempunyai misi dan perencanaan strategis serta tujuan dalam rangka pengembangan masyarakat; 3) Mampu mencapai kemandirian finansial melalui pengembangan dan pelaksanaan rencana bisnis yang realitis; 4) Merekrut tim manajemen yang handal dan memberikan kompensasi yang sesuai; 5) Membangun komitmen para pendiri terhadap pencapaian misi inkubator bisnis dalam memaksimalkan peran manajemen dalam mengembangkan inkubator yang berhasil; 6) Mengutamakan pelayanan kepada tenant termasuk konsultasi yang proaktif dan membuat acuan dalam upaya mencapai kesuksesan dari inkubator; 7) Mengembangkan fasilitas, sumber daya, metode dan alat inkubator dalam rangka memberikan pelayanan terhadap tenant; 8) Mengintegrasikan program dan kegiatan inkubator kepada masyarakat dan berkontribusi kepada pembangunan ekonomi yang lebih luas; 9) Menggalang dukungan stakeholder termasuk membangun jaringan yang membantu tenant untuk mewujudkan misi dan operasi inkubator; dan 10) Memelihara sistem informasi manajemen, mengumpulkan data statistik dan informasi penting yang terkait dalam rangka pelaksanaan program evaluasi. Sehingga dapat meningkatkan efektivitas program dan mampu menyesuaikan terhadap kebutuhan tenant. 
Menurut Bank Indonesia (2006) tidak adanya dua inkubator yang menawarkan jasa yang sama merupakan salah satu aspek yang menarik dari inkubator. Ada yang hanya fokus pada industri teknologi canggih sementara yang lain dapat mengakomodasi perusahaan manufaktur dalam tempat yang sama.

Dalam buku panduan Inkubator Bisnis Teknologi yang diterbitkan oleh LIPI (2014) terdapat beberapa tahapan Inkubasi Bisnis. Pada tahun pertama atau disebut dengan inkubasi tahap persiapan, bagi inkubator yang lolos seleksi maka akan mendapatkan pendanaan untuk mendukung tenant yang akan disiapkan menjadi 26 pengusaha pemula. Dukungan pendanaan tersebut dalam bentuk kegiatan (LIPI, 2014): (1) Pendampingan Pengurusan Pembentukan Legalitas Usaha yaitu Inkubator bertanggung jawab dalam mendampingi tenant dalam pengurusan legalitas usaha. (2) Memberikan pembimbingan pelatihan teknis dan manajemen Dalam proses pendirian perusahaan pemula berbasis teknologi, maka inkubator berkewajiban memberikan pelatihan terkait dengan proses produksi, pengurusan legalitas HKI, penyususan rencana usaha, manajemen keuangan, manajemen pemasaran, dan manajemen produksi. (3) Pendampingan Penyusunan Rencana Usaha. (4) Pendampingan dalam Mencarikan Sumber Pendanaan yaitu Inkubator berkewajiban mencarikan sumber pendanaan untuk merealisasikan terbentuknya PPBT tersebut, baik yang bersifat insentif dari pemerintah maupun lembaga finansial (perbankan maupun non bank) (5) Pendampingan Proses Produksi Sesuai dengan Standarisasi yaitu Inkubator berkewajiban melakukan pendampingan dalam proses produksi yang sesuai dengan standarisasi. Kegiatan ini dimulai dari permulaan produksi skala uji coba sampai skala produksi riil atau sesuai dengan kapasitas yang diinginkan, dan sesuai dengan standarisasi proses dan produk. (6) Pendampingan Tes Pasar yaitu Inkubator berkewajiban mendampingi tenant dalam pengujian pasar.

Idris (2012) menjelaskan, kegiatan rintisan penerapan model inkubator pada tahun 2012 di Indonesia ditujukan pada sosialisasi dan menginformasikan rintisan model yang telah dilakukan oleh inkubator dari 4 perguruan tinggi dalam rangka pengembangan. Adapun 4 (empat) model inkubator rintisan tersebut adalah sebagai berikut (Idris, 2012) (1) Model Inkubator Green Energy (Energi Ramah Lingkungan) (2) Model Inkubator Manufacturing (3) Model Inkubator Industri Kreatif (4) Model Inkubator Agrobisnis.

\section{Kinerja}

Kinerja adalah suatu keadaan yang berkaitan dengan keberhasilan organisasi dalam menjalankan misi yang dimilikinya yang dapat diukur dari tingkat produktivitas, kualitas layanan, responsifitas, responsibilitas, dan akuntabilitas (Tangkilisan, 2005:178). Pengertian kinerja menurut Moeheriono (2012:95) yaitu "Kinerja atau performance merupakan gambaran mengenai tingkat pencapaian pelaksanaan suatu program kegiatan atau kebijakan dalam mewujudkan sasaran, tujuan, visi dan misi organisasi yang dituangkan melalui perencanaan strategis suatu organisasi." (Abdullah, 2014:3). Amstrong dan Baron (1998:15) memberikan pengertian bahwa kinerja merupakan hasil pekerjaan yang mempunyai hubungan kuat dengan tujuan strategi organisasi, kepuasan konsumen dan memberikan kontribusi ekonomi. Kinerja adalah keluaran yang dihasilkan oleh fungsi-fungsi atau indikator-indikator suatu pekerjaan atau suatu profesi dalam waktu tertentu. Kinerja adalah suatu tampilan keadaan secara utuh atas perusahaan selama periode waktu tertentu, merupakan hasil atau prestasi yang dipengaruhi oleh kegiatan operasional perusahaan dalam memanfaatkan sumber daya-sumber daya yang dimiliki (Helfert, 1996 dalam Ceacilia Srimindarti, Fokus Ekonomi, 34 2004:53). 
Perbedaan definisi menurut para ahli tentang pengukuran kinerja dan penilaian kinerja adalah Anderson dan Clancy (Yuwono, et al, 2002: 21), mendefinisikan pengukuran kinerja sebagai "Feedback from the accountant to management that provides information about how well the action represent the plants; it also identifies where manager may need to make corrections or adjustment in future planning and controlling activities." Pengukuran kinerja merupakan suatu tolok ukur bagi manajemen perusahaan dalam menentukan kebijakan perusahaan, apakah kinerja perusahaan sudah baik dari segi keuangan maupun non keuangan.

\section{Penelitan Terdahulu}

Peran Inkubator Bisnis Perguruan Tinggi dalam Peningkatan Kerja Usaha UKM Pangan (Hasbullah et al:2015). Studi ini bertujuan untuk mengkaji kinerja Inkubator Bisnis Perguruan Tinggi dalam pendampingan usaha tenant dan mengkaji pengaruh program inkubasi terhadap kinerja usaha tenant dalam bidang pangan. Penelitian ini menggunakan metode balanced scorecard. Berdasarkan hasil penelitian, inkubator bisnis secara umum memiliki beberapa keterbatasan, yaitu keterbatasan dalam hal proses, kualitas, dan sarana inkubasi serta keterbatasan dalam hal rendahnya efisiensi dan kemandirian secara finansial.

Peran Pusat Pendampingan Usaha Kecil dan Menengah (P3UKM) dalam Pengembangan UKM di Kota Sukabumi (Fachrudin, 2011). Penelitian ini bertujuan untuk mengkaji apakah pola pendampingan inkubator berperan penting dalam pengembangan UKM. Analisis data menggunakan reduksi data. Hasil penelitian menunjukkan bahwa pola pendampingan yang dilakukan oleh inkubator sangat komprehensif dan berperan penting dalam pengembangan UKM dan UMKM yang dapat dilihat dari penerimaan pembiayaan perbankan yang diterima UMKM binaan, peningkatan omzet, dan jumlah karyawan.

\section{METODE PENELITIAN}

Penelitian dilakukan di Inkubator Bisnis Orangenest Incubiz di Kota Bandung dengan metode wawancara dan analisis data sekunder. Responden yang diwawancara adalah pengelola dan tenant inkubator. Jenis penelitian ini adalah deskriptif kuantitatif. Data yang digunakan dalam penelitian ini adalah data primer berupa hasil wawancara dan sekunder berupa hasil pengolahan data kuesioner yang dibagikan. Data yang diperoleh dianalisis dengan metode balanced scorecard (BSC).

\section{PEMBAHASAN}

Pengukuran Kinerja Inkubator Bisnis Teknologi Orangenest Incubiz Park Key Performance Indicator yang digunakan mengacu pada masterplan Inkubator Bisnis Teknologi Orangenest Incubiz Park. Skor maksimal untuk masing-masing perspektif yaitu perspektif internal, inovasi dan pengembangan, finansial, dan tenant adalah 25. Skor keempat perspektif apabila dijumlahkan akan menghasilkan skor kinerja inkubator dengan skor maksimal 100.

Sasaran strategis manajemen didalamnya meliputi staf yang bekerja di dalam Tim Inkubator. Sasaran strategis inkubasi meliputi kegiatan inkubasi yang dilaksanakan oleh Tim Inkubator Bisnis Teknologi Orangenest Incubiz Park. Selama dua tahun masa inkubasi, tenant ditargetkan mengikuti pelatihan sebanyak enam kali pertahun, pameran produk 
sebanyak tiga kali pertahun, temu usaha dua kali pertahun, mendapatkan fasilitas pembiayaan satu kali pertahun serta pada akhir tahun akan diadakan evaluasi terhadap kinerja tenant.

Tabel 1. Hasil Perhitungan Skor Perspektif Internal

\begin{tabular}{|c|c|c|c|c|c|}
\hline $\begin{array}{l}\text { Sasaran } \\
\text { Strategis }\end{array}$ & KPI & Satuan & Target & Tercapai & \\
\hline \multirow[t]{13}{*}{ Sarana } & $\begin{array}{ll}\text { Luas } & \text { Kantor } \\
\text { Manajemen } & \end{array}$ & $\mathrm{m}^{2}$ & 43.2 & 162.88 & 377.037 \\
\hline & Jumlah Ruang Tenant & Unit & 12 & 21 & 175 \\
\hline & Luas Rataan/Tenant & $\mathrm{m}^{2}$ & 16 & 15.12 & 94.5 \\
\hline & Ruang Rapat & $\mathrm{m}^{2}$ & 60.84 & 60.84 & 100 \\
\hline & Ruang Pelatihan & $\mathrm{m}^{2}$ & 81 & 48.6 & 60 \\
\hline & Komputer & Skor & 5 & 5 & 100 \\
\hline & Internet & Skor & 5 & 3 & 60 \\
\hline & Laboratorium & Skor & 5 & 1 & 20 \\
\hline & Website Inkubator & Skor & 5 & 1 & 20 \\
\hline & $\begin{array}{ll}\text { Outlet } & \text { Pemasaran } \\
\text { Bersama } & \\
\end{array}$ & Skor & 5 & 1 & 20 \\
\hline & E-market Produk & Skor & 5 & 1 & 20 \\
\hline & Ruang Seminar & Skor & 5 & 5 & 100 \\
\hline & Working Space & Skor & 5 & 5 & 100 \\
\hline \multirow[t]{5}{*}{ Manajemen } & Staf Penuh Waktu & Orang & 8 & 4 & 50 \\
\hline & Staf Paruh Waktu & Orang & 3 & 1 & 33.333 \\
\hline & Pendidikan Manajer & Skor & 5 & 3 & 60 \\
\hline & Staf Administrasi & Orang & 2 & 0 & 0 \\
\hline & Jumlah Pendamping & Orang & 8 & 3 & 37.5 \\
\hline \multirow[t]{7}{*}{ Inkubasi } & Masa Inkubasi & Tahun & 2 & 2 & 100 \\
\hline & Intensitas Kunjungan & $\begin{array}{l}\text { Kali/ } \\
\text { tahun }\end{array}$ & 24 & 12 & 50 \\
\hline & Pelatihan & $\begin{array}{l}\text { Kali/ } \\
\text { tahun }\end{array}$ & 6 & 2 & 33.333 \\
\hline & Pameran Produk & $\begin{array}{l}\text { Kali/ } \\
\text { tahun }\end{array}$ & 3 & 3 & 100 \\
\hline & Temu Usaha & $\begin{array}{l}\text { Kali/ } \\
\text { tahun }\end{array}$ & 2 & 1 & 50 \\
\hline & Fasilitas Pembiayaan & $\begin{array}{l}\text { Kali/ } \\
\text { tahun }\end{array}$ & 1 & 1 & 100 \\
\hline & Monev & Kali/ & 1 & 1 & 100 \\
\hline
\end{tabular}




\begin{tabular}{|c|c|c|c|c|c|}
\hline Sasaran & \multirow[b]{2}{*}{ KPI } & \multirow[b]{2}{*}{ Satuan } & \multirow[b]{2}{*}{ Target } & \multirow{2}{*}{\multicolumn{2}{|c|}{ Tercapai }} \\
\hline \multirow[b]{2}{*}{ Strategis } & & & & & \\
\hline & & & & & $\frac{\text { Tercapai }}{\text { Target }} \times 100$ \\
\hline & & tahun & & & \\
\hline \multicolumn{5}{|c|}{ 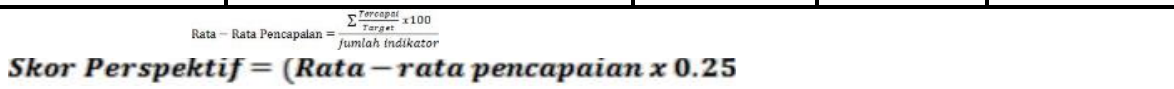 } & 78.428 \\
\hline Sther rerpentit & & & & & 19.607 \\
\hline
\end{tabular}

Sumber : Data Primer 2018 (diolah)

Berdasarkan tabel diatas dapat disimpulkan bahwa skor pencapaian untuk perspektif internal adalah 19.607. Sasaran strategis sarana terdapat beberapa hal yang perlu ditingkatkan dalam pencapaian target antara lain penyediaan internet, laboratorium, website inkubator, outlet pemasaran bersama, dan e-market produk. Tim Inkubator Bisnis dan Teknologi Orangnest Incubiz Park belum memiliki staf administrasi dalam hal ini pendamping merangkap sebagai staf administrasi.

Sasaran strategis dalam perspektif inovasi dan pengembangan terdiri dari sisi inkubator dan kinerja usaha tenant. Layanan program inkubasi dalam hal pengembangan bisnis dan akses pemodalan yang diberikan oleh inkubator tedapat dalam perspektif inovasi dan pengembangan.

Tabel 2. Hasil Perhitungan Skor Perspektif Inovasi dan Pengembangan

\begin{tabular}{|c|l|l|c|c|c|}
\hline $\begin{array}{c}\text { Sasaran } \\
\text { Strategis }\end{array}$ & \multicolumn{1}{|c|}{ KPI } & Satuan & Target & Tercapai & \\
\hline Inkubator & Jejaring Inkubator & Organis & 15 & 6 & 46.667 \\
\hline & Bisnis & asi & & & \\
\hline & & & & & 50 \\
\hline & Jumlah Tenant & Orang & 10 & 4 & 25 \\
\hline \multirow{3}{*}{$\begin{array}{c}\text { Usaha } \\
\text { Tenant }\end{array}$} & $\begin{array}{l}\text { Jumlah Tenant } \\
\text { Pemasaran Produk }\end{array}$ & Orang & 10 & 2 & 31.818 \\
\cline { 2 - 6 } & $\begin{array}{l}\text { Peningkatan Omzet } \\
\text { Rata-rata Tahunan } \\
\text { Tenant }\end{array}$ & Persen & 55 & 30 & 45.455 \\
\cline { 2 - 6 } & $\begin{array}{l}\text { Peningkatan } \\
\text { Jumlah Tenaga }\end{array}$ & $\begin{array}{l}\text { Persen/ } \\
\text { tahun }\end{array}$ & 27.5 & 25 & \\
\hline
\end{tabular}


Jurnal Manajemen dan Bisnis: Performa Vol.16, No. 1 Maret 2019

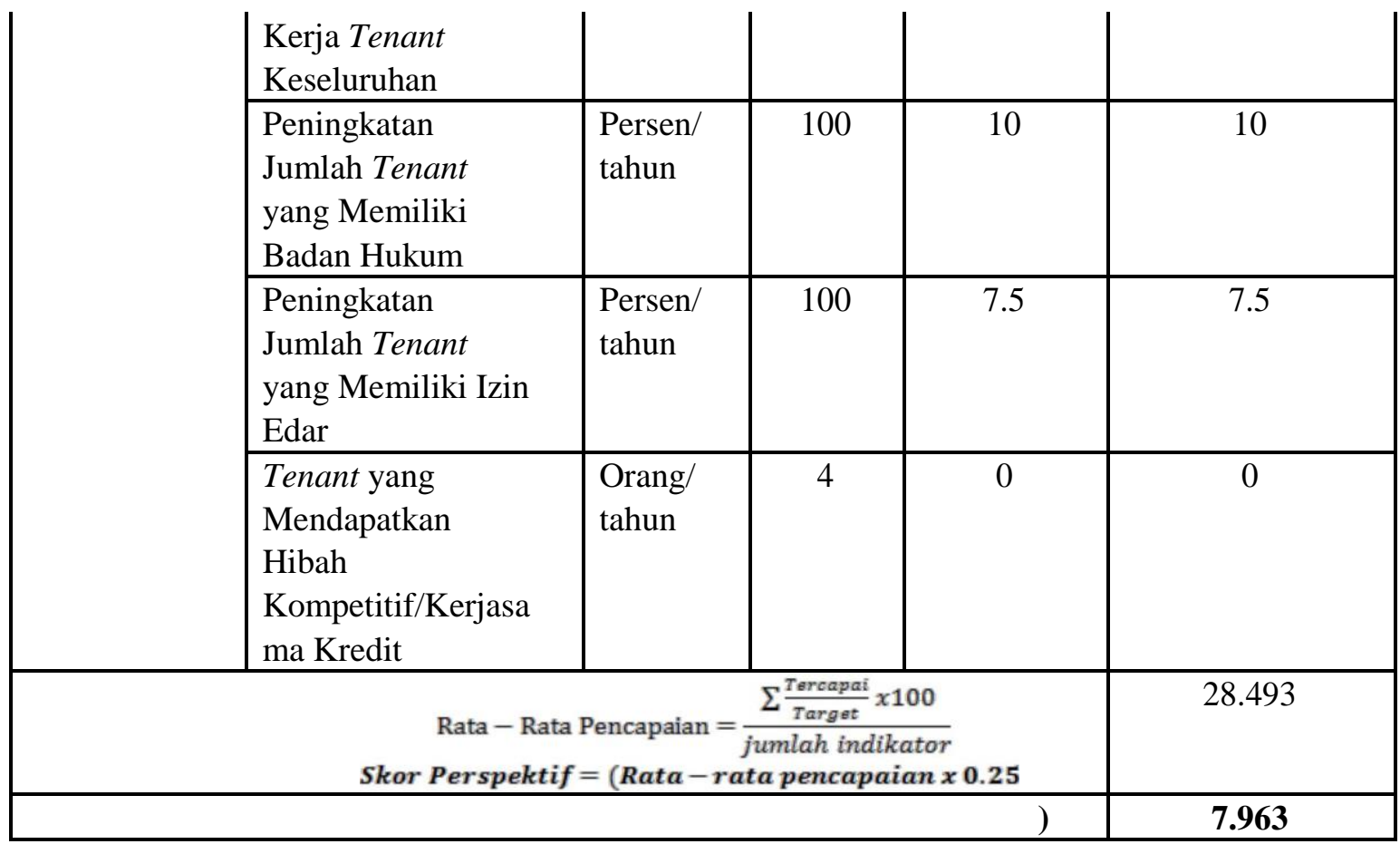

Sumber data : Data Primer 2018(diolah)

Berdasarkan tabel 2 dapat disimpulkan bahwa skor yang dicapai oleh perspektif inovasi dan pengembangan adalah 7.963. Skor ini terbilang kecil jika dibandingkan dengan skor maksimal perspektif yaitu 25. Dari tabel diatas layanan program inkubasi inkubator belum dapat dikatakan berjalan dengan maksimal jika dibandingkan dengan skor maksimal perspektif yaitu 25. Jangkauan pemasaran produk hanya mendapatkan skor 2 dari skor maksimal yaitu 5. Skor ini mencerminkan bahwa jangkauan pemasaran produk belum memuaskan. Peningkatan omzet rata-rata tahunan tenant juga masih rendah jika dibandingkan dengan target. Target peningkatan omzet sebesar 55\% sedangkan yang tercapai hanya 30\%. Peningkatan jumlah tenant yang memiliki badan hukum juga masih sangat kecil yaitu hanya $10 \%$ dari taget yang ditentukan yaitu $100 \%$. Peningkatan jumlah tenant yang memiliki izin edar hanya 7,5\% sedangkan target peningkatan jumlah tenant yang memiliki izin edar adalah $100 \%$. Hingga saat ini, masih belum ada ada tenant yang mendapatkan hibah kompetitif/kerjasama kredit.

Perspektif keuangan, memberikan sasaran keuangan yang perlu dicapai oleh organisasi dalam mewujudkan visinya. Sasaran strategis dalam perspektif keuangan adalah efisiensi keuangan dengan indikator rasio pendapatan terhadap biaya pengelolaan Inkubator Bisnis Teknologi Orangenest Incubator. Inkubator Bisnis Teknologi Orangenest Incubiz Park saat ini menerima pendapatan dari pelatihan, riset pasar dan sewa tempat. Pendapatan tersebut biasanya dihasilkan dari biaya sewa ruang tenant. Namun, hingga saat ini Inkubator Bisnis Teknologi Solo Technopark masih memberikan kebebasan biaya untuk ruang tenant. Pembiayaan operasional Inkubator Bisnis Teknologi Orangenest Incubiz Park berasal dari dana yang diberikan oleh Kemenristekdikti dan Pendapatan Usaha

Perspektif tenant memberikan gambaran mengenai tuntutan kebutuhan yang harus diberikan oleh Inkubator Bisnis Teknologi kepada tenant. Inkubator bisnis memberikan beberapa layanan kepada para tenant dalam mendampingi usaha tenant. 
Jurnal Manajemen dan Bisnis: Performa Vol.16, No. 1 Maret 2019

Tabel 3. Hasil Perhitungan Skor Perspektif Tenant

\begin{tabular}{|c|c|c|c|c|c|}
\hline $\begin{array}{l}\text { Sasaran } \\
\text { Strategis }\end{array}$ & KPI & Satuan & Target & Tercapai & $\frac{\text { Tercapai }}{\text { Target }} \times 100$ \\
\hline \multirow{7}{*}{$\begin{array}{c}\text { Kepuasan } \\
\text { Tenant }\end{array}$} & Sistem Rekruitmen & Skor & 5 & 4.5 & 90 \\
\hline & Pelatatihan & Skor & 5 & 4 & 80 \\
\hline & $\begin{array}{l}\text { Sistem Dukungan } \\
\text { dan Fasilitas }\end{array}$ & Skor & 5 & 4.333 & 86.667 \\
\hline & $\begin{array}{l}\text { Dukungan Sarana } \\
\text { Prasarana Produksi }\end{array}$ & Skor & 5 & 4.333 & 86.667 \\
\hline & $\begin{array}{l}\text { Pengelola dan Tim } \\
\text { Pendamping } \\
\text { Inkubator Bisnis } \\
\text { Memberikan } \\
\text { Motivasi }\end{array}$ & Skor & 5 & 4.667 & 93.333 \\
\hline & $\begin{array}{l}\text { Pertemuan dan } \\
\text { Diskusi }\end{array}$ & Skor & 5 & 4.167 & 83.333 \\
\hline & $\begin{array}{l}\text { Puas dengan } \\
\text { Layanan } \\
\text { Administrasi } \\
\end{array}$ & Skor & 5 & 4 & 80 \\
\hline \multirow[t]{5}{*}{$\begin{array}{l}\text { Pertumbuhan } \\
\text { Usaha }\end{array}$} & $\begin{array}{l}\text { Mendapatkan } \\
\text { Perluasan Network }\end{array}$ & Skor & 5 & 4.333 & 86.667 \\
\hline & $\begin{array}{l}\text { Lingkung dan } \\
\text { Jaringan } \\
\text { Pemasaran } \\
\text { Perusahaan } \\
\text { Meningkat } \\
\end{array}$ & Skor & 5 & 4.333 & 86.667 \\
\hline & $\begin{array}{l}\text { Jumlah Karyawan } \\
\text { dan Kualitas Kerja } \\
\text { Meningkat }\end{array}$ & Skor & 5 & 4.333 & 86.667 \\
\hline & $\begin{array}{l}\text { Kualitas Produk } \\
\text { dan Kapasitas } \\
\text { Produksi } \\
\text { Meningkat } \\
\end{array}$ & Skor & 5 & 4.5 & 90 \\
\hline & $\begin{array}{l}\text { Omzet Perusahaan } \\
\text { Meningkat }\end{array}$ & Skor & 5 & 4.667 & 93.333 \\
\hline \multicolumn{5}{|c|}{$\sum \frac{\text { Tercapai }}{\text { Target }} \times 100$} & 87.190 \\
\hline \multicolumn{5}{|c|}{ Skor Pencapaian = Rata-rata Pencapaian x 0.25} & 21.798 \\
\hline
\end{tabular}

Sumber: Data yang diolah,2018 
Tabel 3 menunjukkan bahwa perspektif tenant memberikan kontribusi yang besar yaitu 21.798. Angka ini menunjukkan kinerja perspektif mendekati maksimal skor setiap perspektif yaitu 25. Sejauh ini tenant merasa puas dengan layanan yang diberikan oleh Tim Inkubator Bisnis dan Teknologi Orangenest Incubiz Park.

Menurut hasil wawancara dengan tenant sistem rekruitmen Inkubator Bisnis Teknologi Orangenest Incubiz Park tidak membutuhkan waktu yang lama. Proses seleksi hingga pengumuman hanya membutuhkan waktu maksimal satu bulan. Hal ini berbeda dengan sistem rekruitmen di Kemenristekdikti yang membutuhkan waktu lebih dari satu bulan. Walaupun demikian, proses seleksi tenant tetap dievaluasi oleh pihak Kemenristekdikti.

Skor pencapaian kinerja Inkubator Bisnis Teknologi Solo Technopark didapatkan dari penjumlahan skor keempat perspektif yaitu perspektif internal, perspektif inovasi dan pengembangan, perspektif finansial, dan perspektif tenant.

Tabel 5. Skor Pencapaian Kinerja Inkubator Bisnis

\begin{tabular}{|c|c|c|c|}
\hline \multicolumn{4}{|c|}{ Perspektif } \\
\hline Internal & $\begin{array}{c}\text { Inovasi } \\
\text { dan } \\
\text { Pengembangan }\end{array}$ & Finansial & $\begin{array}{c}\text { Kepuasan } \\
\text { Tenant }\end{array}$ \\
\hline $\mathbf{1 9 . 6 0 7}$ & $\mathbf{7 . 1 2 3}$ & $\mathbf{0}$ & $\mathbf{2 1 . 7 9 8}$ \\
\hline \multicolumn{3}{|c}{ Total $=\mathbf{4 8 . 5 2 8}$} \\
\hline
\end{tabular}

Sumber : Hasil Olah Data (2018)

Skor pencapaian kinerja inkubator bisnis adalah 48.528. Hasil perhitungan menunjukkan mutu kinerja Inkubator Bisnis Teknologi Orangenest Incubiz Park belum memuaskan sehingga membutuhkan tindakan lebih lanjut. Menurut Price Water House Coopers mutu kinerja yang memuaskan apabila total skor semua persperktif lebih dari 85 .

Berdasarkan tabel 5 dapat disimpulkan bahwa skor setiap perspektif sangat beragam. Namun secara umum dapat dilihat bahwa skor perspektif inovasi dan pengembangan serta finansial memberikan kontribusi yang rendah terhadap skor kinerja. Tabel diatas menunjukkan bahwa Inkubator Bisnis Teknologi Orangenest Incubiz Park secara umum memiliki dua keterbatasan utama. Pertama, keterbatasan dalam hal proses peningkatan kinerja usaha tenant. Kedua, Inkubator Bisnis Teknologi Orangenest Incubiz Park masih rendah dalam hal efisiensi dan kemandirian secara finansial. Perspektif finansial menunjukkan angka 0 hal ini dikarenakan struktur pembiayaan operasional Inkubator Bisnis Teknologi Orangenest Incubiz park masih bergantung pada pendanaan pemerintah yang bersifat project/program,sehingga keberlangsungan kegiatan/aktivitas inkubasi sangat bergantung pada ada atau tidaknya dana program tersebut.

Survei kinerja usaha tenant yang telah dilakukan terhadap responden Inkubator Bisnis Teknologi Orangnest Incubator menggunakan empat indikator utama yaitu peningkatan omzet, peningkatan jumlah tenaga kerja, peningkatan kapasitas produksi, dan perolehan 
bantuan modal usaha baik kredit dari perbankan, PKBL BUMN, hibah ataupun sumber permodalan lainnya.

Berdasarkan penelitian yang telah dilakukan, dalam peningkatan omzet rata-rata per tahun terdapat empat tenant yang mengalami peningkatan omzet sebesar 26\%-50\% per tahun dan dua tenant mengalami peningkatan omzet sebesar 51\%-75\% pertahun. Salah satu tahapan kegiatan inkubasi, yaitu fasilitas promosi dan pemasaran produk tenant. Inkubator membantu mempromosikan produk tenant dalam berbagai ajang kegiatan, seperti pameran, workshop, seminar, serta outlet pemasaran bersama. Kegiatan tersebut sangat memberikan manfaat dan berdampak terhadap peningkatan omzet usaha. Berdasarkan hasil penelitian, tenant yang mengalami peningkatan jumlah tenaga kerja pertahun sebesar 76\%-100\% sebanyak empat tenant sedangkan dua tenant lainnya mengalami peningkatan sebesar 51\%-75\%. Dengan adanya peningkatan jumlah tenaga kerja hal ini juga berdampak pada kapasistas produksi. Terdapat 3 tenant yang mengalami peningkatan kapasitas produksi sebesar $51 \%-75 \%$ sedangkan 3 tenant lainnya sebesar 76\%-100\%. Berdasarkan hasil survey diketahui bahwa setelah menjadi tenant Inkubator Bisnis, hanya sedikit tenant yang mendapatkan peluang untuk mendapatkan pembiayaan usaha tenant. Peningkatan kemudahan dalam mendapatkan pembiayaan usaha hanya $0-25 \%$.

\section{KESIMPULAN}

Berdasarkan hasil penelitian dan pembahasan mengenai analisis kinerja inkubator bisnis Orangenest dalam pendampingan usaha tenant dan peningkatan kinerja usaha tenant, maka dapat disimpulkan : (1) Kinerja Inkubator Bisnis dalam Pendampingan Usaha Tenant Berdasarkan analisis balanced scorecard yang dilakukan pada Inkubator Bisnis Teknologi Orangenest Incubator perspektif internal mendapatkan skor sebesar 19.607, perspektif inovasi dan pengembangan mendapatkan skor sebesar 7.963, perspektif finansial mendapatkan skor sebesar 0, dan perspektif tenant mendapatkan skor sebesar 7.963. Skor pencapaian kinerja Inkubator Bisnis Teknologi Orangenest Incubator adalah 48.528 . Berdasarkan hasil tersebut, peran Inkubator Bisnis Teknologi Orangnest Incubator menurut Price Waterhouse Coopers dalam pendampingan usaha tenant menunjukkan bahwa Inkubator Bisnis Teknologi Orangenest Incubator diperlukan tindakan lebih lanjut.

Inkubator Bisnis Teknologi Orangnest Incubator telah memberikan manfaat sehingga berdampak terhadap peningkatan kinerja usaha tenant. Peningkatan kinerja usaha tersebut adalah (1) Terdapat empat tenant yang mengalami peningkatan omzet sebesar $26 \%-50 \%$ per tahun. Dua tenant mengalami peningkatan omzet sebesar 51\%-75\% per tahun.(2) Terdapat empat tenant yang mengalami peningkatan jumlah tenaga kerja sebesar $76 \%-100 \%$ per tahun. Dua tenant lainnya mengalami peningkatan jumlah tenaga kerja sebesar $51 \%-75 \%$ per tahun.

(3) Peningkatan kemudahan dalam mendapatkan pembiayaan usaha hanya $0-25 \%$.

\section{DAFTAR PUSTAKA}




\section{Jurnal Manajemen dan Bisnis: Performa Vol.16, No. 1 Maret 2019}

Abdullah, Ma'ruf. (2014). Manajemen dan Evaluasi Kinerja Karyawan. Yogyakarta: Aswaja Pressindo.

Agustina, Tri Siwi. (2011). Peran Inkubator Bisnis Perguruan Tinggi dalam Meminimalkan Resiko Kegagalan Bagi Wirausaha Baru pada Tahap Awal (Start-up). Surabaya: Fakultas Ekonomi dan Bisnis Universitas Airlangga.

Amstrong dan Baron. 1998. Perfect Management. London: Institute of Personal and Development.

Aninda, Nuraisyah. (2017) Analisa Kinerja pendampingan bisnis usaha rintisan incubator Teknologi terhadap usaha rintisan (Studi Kasus pada Incubator Solo Technopark), Universitas Sebelas Maret.

Badan Pusat Statistik. (2013). Proyeksi Penduduk Indonesia 2010-2035. Jakarta:Badan Pusat Statistik

Barrow,Colin,(2001).Incubators:A Realist"s Guide to the World"s New Business Accelerators. London: John Willey \& Son, Ltd.

Campbell, C., \& Allen, D. N. (1987). The small business incubator industry: micro-level economic development. Economic Development Quarterly, 1(2), 178-191.

Chandra A dan Chao C. (2011). Growth and evolution of high-technology business incubation in China. Human Systems Management. 30(1 2): 55-59

Coopers, P. W. (1999). National Review of Small Business Incubators. Final Report.

Daft, Richard L. (2008). The Leadership Experrience, Fourth Edition.. Ohio:Thomson Learning Academic Resource Ce

Darmadi, Hamid. (2013). Metode Penelitian Pendidikan dan Sosial. Bandung:Alfabeta.

Dewi, Yovita Anggita. (2012). Inovasi Spesifik Lokasi untuk Inkubator Bisnis dan Teknologi Mendukung Pengembangan Ekonomi Lokal. Jurnal Analisis Kebijakan Pertanian vol. 10 No.4 Desember 2012: 299-312.

Dipta, I Wayan, (2003). Inkubator Bisnis dan Teknologi Sebagai Wahana Pengembangan Usaha Kecil Memasuki Era Global. Jakarta:INFOKOP,

Fachrudin, Ridwan. (2011). Peran Pusat Pendampingan Usaha Kecil dan Menengah (P3UKM) dalam Pengembangan UKM di Kota Sukabumi (Skripsi). Jakarta: UIN

Friedrich Ebert Stiftung. (2010). UMKM Pilar Kemandirian Bangsa. Jurnal Sosial Demokrasi. Jakarta: Pergerakan Indonesia dan Komite Persiapan Yayasan Indonesia Kita

Hakim, Muhammad. (2015). Pengaruh Pendampingan Inkubator Wirausaha terhadap Kinerja Keuangan UMKM Tenant Jambi (Studi Kasus UMKM Tenant Inkubator Bisnis Unggul FEB UNJA) (Skripsi). Jambi:Universitas

http://nasional.kompas.com(diakses pada tanggal 27 Maret 2017)

Peraturan Presiden RI Nomor 27 Tahun 2013 